\title{
El periodismo comprometido Juan Pablo Cárdenas Ediciones Radio Universidad de Chile, 2006 139 páginas
}

\author{
Raúl MUÑ̃Z CHAUT
}

Nueve artículos escritos durante los años 2004 al 2006, para ponencias o conferencias, constituyen e integran este libro editado por la Radio de la Universidad de Chile.

Se trata de textos provocadores y provocativos por cuanto no solo incitan o estimulan la reflexión, sino también tienen la virtud o eficacia de contribuir a lo anterior. A través de ellos, el autor hace un recorrido por el deber ser del periodismo y las comunicaciones, pero también es un recorrido por muchas debilidades y desafíos que marcan la sociedad actual chilena.

El primero de los trabajos "Ser Periodista, Hoy y Mañana" (2006) resalta las condiciones del trabajo periodístico, colocando el acento en el deber ser ético del profesional y considera el espacio abierto por Internet como una oportunidad favorable a la democracia.

"Democracia y Política de Comunicaciones" (2005) resalta la necesidad de contar con un pluralismo informativo, terminar con la autocensura en los medios y la responsabilidad que le compete en esta tarea a las instituciones formadoras de periodistas .

"Periodismo y Proceso Político Chileno" (2004) coloca en el tapete asuntos de la llamada transición, con el cierre de diferentes medios, una inapropiada distribución de los recursos publicitarios que dependían de los gobiernos de la Concertación y la instalación de formas de proceder que son propias de una corrupción (tema tan candente en la actualidad).

Considerar a la radio como uno de los medios más recurridos hoy en día es el eje de "América Latina y las Fortalezas de la Radiodifusión" (2005). Se hace un reconocimiento a aquellas emisoras que primero se proponen informar, luego educar entregando también la necesaria entretención. Además, se señala que existe un mayor grado de credibilidad puesto que la mentira y la tergiversación tienen menos sitio en la radio.

En "Periodistas, Conflictos Sociales y Reconciliación" (2005) se destaca lo crucial que resulta ser el trabajo periodístico para la edificación de una real democracia. Sin aquella es impensable la instalación de esta última.

"Televisión, Basura y Democracia" (2006) nos habla de la vulgarización dominada por el reitin, lo cual, a su vez implica un contrabando ideológico de proporciones pues se hace de modo soterrado. En opinión del autor, se trata de una responsabilidad pendiente de parte del Estado para efectivamente impulsar una verdadera televisión pública en Chile.

La dicotomía entre la formación académica tecnicista versus el rol educacional deseable es examinada en "El Trasvestismo de los Medios de Comunicación" (2004). Fuertemente es contrastado el fenómeno de cómo el reitin y el tiraje van definiendo los contenidos de la televisión, de la radio y de la prensa escrita. Este hecho marca que lo vulgar y superficial genera una uniformidad comunicacional, que poco y nada tiene que ver con el verdadero trabajo profesional del periodismo. 
A través de lo expuesto en "Los Ciudadanos y el Periodismo" (2004), se alude a como asumiendo una falta de compromiso por parte de los periodistas, eso resulta ser lo más sensato y lucrativo. En circunstancias de que una sociedad organizada aspira a que ella misma sea capaz de sostener sus propios medios de comunicación. Sin embargo, el exitismo presente confiere a las empresas y a los empresarios el desafío de ganar más, en menos tiempo y con menos mano de obra. Se vuelve a insistir en la responsabilidad directa de las escuelas de periodismo en los modelos académicos que impulsan en sus respectivas universidades para la formación de profesionales, sobre todo en un abanico de ofertas donde no siempre resulta fácil distinguir el grano de la paja.

Finalmente, "Manifiesto sobre la Pobreza" (2006) consigna las aplicaciones del modelo económico actualmente vigente que ha aumentado la pobreza en lugar de disminuirla. Donde se ha reducido la clase media a un $25 \%$ y se ha privilegiado de modo escandaloso a un $2 \%$ de la población. La connivencia de los grandes medios con la política cupular y los grupos de presión se ha transformado en una práctica regular para que los frutos de los acuerdos logrados sirvan a una minoría y no a la mayoría. Por lo tanto, a juicio del autor, la equidad es el gran concepto que se constituye en la base de un verdadero proyecto-país.

En consecuencia, se podrá estar de acuerdo o no con las ideas contenidas en este compendio, pero no podrá existir indiferencia. 